\title{
New occurrences of corticioid and poroid fungi (Basidiomycota) in Kedrovaya Pad Nature Reserve, Primorye Territory, Russian Far East
}

\author{
Ilya A. Viner \& Lyudmila Yu. Kokaeva \\ Moscow State University, Faculty of Biology, Russia. \\ E-mail: viner.ilya@gmail.com, kokaeval@gmail.com
}

\begin{abstract}
New data on corticioid and poroid basidiomycetes from Kedrovaya Pad Nature Reserve, Primorye Territory, Russian Far East, is presented. Altogether there are 182 known species from the reserve; 76 are reported as new to the reserve and two as new to Russia. The material was collected in July of 2016 from 9 study plots located in forests of different types. Findings of some rarely collected species such as Botryobasidium botryoideum, Cerinomyces aff. aculeatus, Junghuhnia aurantilaeta, Phanerochaete robusta and Tyromyces wynneae are briefly discussed. The full-length ITS sequences of Junghuhnia aurantilaeta, Phanerochaete robusta, Pyrrhoderma cf. sendaiense and Tyromyces wynneae were obtained and deposited in the GenBank. Junghubnia aurantilaeta is proposed to be included in the new edition of the Red Data Book of Primorye Territory. The paper expands the knowledge of distribution of many species and increases the total number of species reported for the reserve.
\end{abstract}

Keywords: biodiversity; corticioids; polypors; Russian Far East

\section{INTRODUCTION}

The Kedrovaya Pad Nature Reserve is located on the coastal spurs of the Manchurian Mountains. The river valley of Kedrovaya river lies between the Gakkelevsky and Sukhorechensky ridges (Fig. 1,2). The microclimate of the reserve is affected by two main factors: warm humid air masses from the Philippines and a mountainous relief, which acts as a wind tunnel and transports moist air from the sea. As a result, the reserve is warmer and wetter in comparison with adjacent territories. Nature protection measures have been implemented in the area since 1916 supporting the forest conservation. The forest cover is unique in a sense that subtropical and coniferous-broadleaf forests overlap, which leads to a high diversity of plant and fungal species (www.unesco.org).

The data of the biodiversity of aphyllophoroid fungi in the reserve was reported by Nikolayeva (1967), Vassiljeva (1972) and Parmasto $(1968,1970)$ and summarized by Korkishko (2002). Moreover Kovalenko et al. (2012) listed some species. Before our study, only limited emphasis was made on aphyllophoroid fungi, and only 105 species were reported from the reserve (Korkishko, 2002; Kovalenko et al., 2012). We propose Junghuhnia aurantilaeta (Corner) Spirin as a good candidate for the new edition of the regional Red Data Book.

\section{MATERIALS AND METHODS}

Fruit bodies were collected in Kedrovaya Pad Nature Reserve, Primorye Territory, Russian Far East (Fig. 1), near Primorskaya station $\left(43^{\circ} 05^{\prime} 42^{\prime \prime N}, 131^{\circ} 35^{\prime} 6^{\prime \prime} \mathrm{E}\right)$, Khasanskiy district in 24-31 July 2016. The studied area was comprised of nine forest sites (approximately 1 ha each, Fig. 2): herb rich oak (Quercus mongolica Fisch. ex Ledeb.) forest on eastern slope (1), coniferous-broadleaf forest (2), coniferous-broadleaf forest on northern slope (3), mixed Krummholz stand with fir (Abies holophylla Maxim.), birches (Betula spp.), maples (Acer spp.), oak and pine (Pinus koraiensis Siebold \& Zucc.) (4), oak forest with maples and birches on southern slope (5), willow (Salix spp.) forest with maples (6), fern-maple-oak forest on fluvial terrace (7), conifer forest with fir and pine (8) and (9) coniferous-broadleaf forest with amur cork tree (Phellodendron amurense Rupr.). Each site was visited once. All sites were characterized by large amounts of dead wood except broadleaf forests $(1,5,7)$ and Krummholz stand (4). Surveyed woody remnants were chosen randomly. Fragments of each fruit body were collected for microscopic identification using Melzer's reagent (IKI) and Cotton Blue (CB). In total, we collected or noted more than 400 specimens of fruit bodies. In the species-list we included all corticioids, polypores and heterobasidioid taxa 


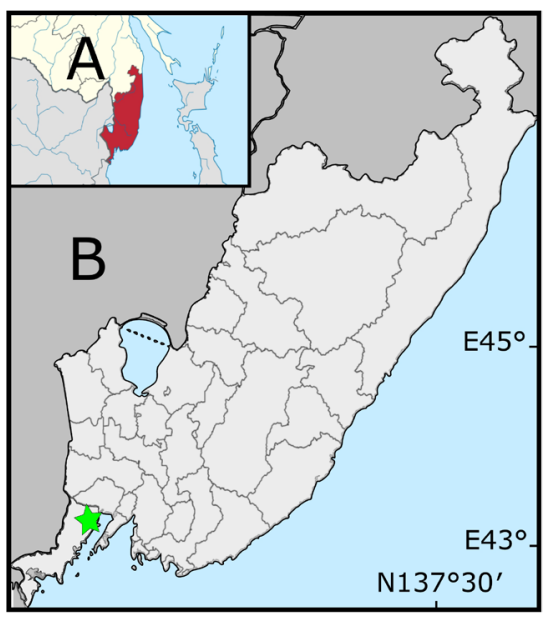

Fig. 1. A - Primorye Territory in Russian Far East, B - Kedrovaya Pad Nature Reserve in Primorye Territory.

like Basidiodendron spp. which are new for the reserve or rarely collected in Russia. The list consists of species names in Latin, followed by the substrate type (in most cases specified only up to angiosperm or gymnosperm wood) and the number of the collection location. Numbered specimens, which were deposited in a personal fungarium, can be requested from the Zoological Club of the Zoological Museum of Moscow University (KUN ZMMU). Duplicates of some specimens were deposited in the mycological collection of University of Helsinki (H). The specimens without number were deposited in the personal fungarium of I.V. The nomenclature follows MycoBank and Index Fungorum. Infraspecific taxa were not specified.

In addition, we obtained new full-length ITS sequences of Junghuhnia aurantilaeta, Phanerochaete robusta Parmasto, Pyrrhoderma cf. sendaiense (Yasuda) Imazeki and Tyromyces wynneae (Berk. \& Broome) Donk. These particular species were selected since there is only a limited number of their sequences in the GenBank and their sequences from such remote areas as Russian Far East can be of interest in taxonomic studies. The large sizes and good preservation of these fruit bodies also facilitate DNA extraction which was difficult for several other species, sequences of which were not included here. The fragments of fruit bodies were grind under liquid nitrogen with a sterile

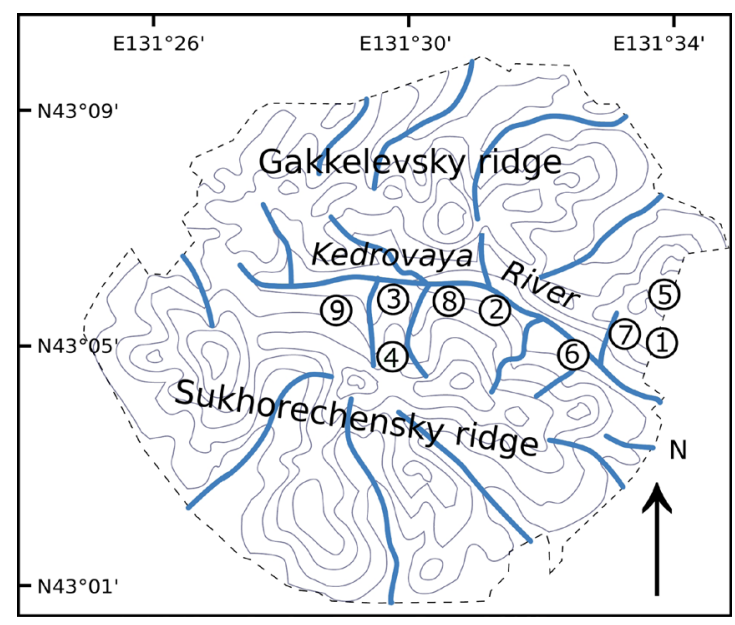

Fig. 2. Kedrovaya Pad Nature Reserve with collecting sites (circles).

pestle in sterilized eppendorf tube. DNA was extracted according to the standard CTAB protocol (Griffith \& Shaw, 1998). rDNA fragments with internal transcribed spacers (ITS) was amplified with the universal primers ITS1 and ITS4 (White et al., 1990). PCR was performed with GenPak ${ }^{\circledR}$ PCR Core kit (Isogene, Russia). The following PCR conditions were used: one cycle for $3 \mathrm{~min}$ at $96{ }^{\circ} \mathrm{C}, 30$ cycles with $30 \mathrm{sec}$ at $94{ }^{\circ} \mathrm{C}, 30 \mathrm{sec}$ at $55^{\circ} \mathrm{C}, 30 \mathrm{sec}$ at $72{ }^{\circ} \mathrm{C}$, and $3 \mathrm{~min}$ at $72{ }^{\circ} \mathrm{C}$. After amplification PCR products were run on a $1.5 \%$ agarose gel stained with ethidium bromide and visualized under the UV light. Amplification product was cut out from agarose gel with sterile scalpel and cleaned with Cleanup Standard kit (Evrogen Ltd, Moscow, Russia). Sequencing reactions were performed by the Evrogen company (Moscow, Russia) following the BigDye terminator protocol (ABI Prism) on an Applied Biosystems $3730 \mathrm{xl}$ automatic sequencer (Applied Biosystems, CA, USA) with both forward and reverse primers. The raw sequence reads were trimmed manually and assembled into consensus sequences in Geneious (Biomatters Limited, Auckland, New Zealand) using default settings. ITS sequences were identified through BLASTn searches in UNITE (https://unite. ut.ee/), the BLASTn search was ran against the International Nucleotide Sequence Databases Consortium (INSDC; http://www.insdc.org) and UNITE (Abarenkov et al., 2010) databases. 
All newly obtained sequences were deposited in the GenBank (http://www.ncbi.nlm.nih.gov/); accession numbers are listed in the species-list.

\section{RESULTS AND DISCUSSION}

In total we found 76 new species for the reserve, two species new to Russia (Korkishko, 2002; Spirin et al., 2007; Kovalenko et al., 2012). Most of our findings were observed on angiosperms, while only a limited number grew on gymnosperms, 69 and 4 respectively. Only 7 taxa grew both on gymnosperms and angiosperms. We collected two species which are included in the Red Data Book of the Primorye Territory: Cryptoporus volvatus (Peck) Shear and Hericium erinaceus (Bull.) Pers. (Baryshenko, 2008). According to our observations, Junghuhnia aurantilaeta could be included in the new edition of the Red Data Book. This species is extremely rarely collected in other parts of Russia: there is only one published record outside Kedrovaya Pad Nature Reserve (Bukharova \& Zmitrovich, 2014). Nevertheless, it was previously collected in the studied area in 1944 and 2005 (Spirin et al., 2007), which indicates a stable population. J. aurantilaeta inhabits gymnosperm and angiosperm dead wood in pristine broadleaf and coniferous-broadleaf forests, which are the main target of forest management in Primorye Territory, so if the forests are cut down, J. aurantilaeta will become threatened. Also, it can be easily identified in the field by non-professional mycologists by the fleshy-tough consistency and orange color of fruit bodies together with comparatively large pores, 1-3 per $\mathrm{mm}$.

\section{Annotated list of species}

The species list is in alphabetical order. One asterisk (*) indicates new records for Nature Reserve, two (**) for Russia. The entries consist of the species name followed by substrate species (when available), personal specimen number (KUN ZMMU 1234) and the number of the collection site (Fig. 2). Short notes are provided for some records. As these records were made in a strictly protected area, we do not provide precise coordinates for the locations.

*ABundisporus pUbertatis (Lloyd) Parmasto - angiosperm wood (KUN ZMMU 2692); 7.

Note. A. pubertatis was reported previously from North-East China and Russian Far east (Dai et al., 2002) and it seems to be one of the most common polypore species in southern part of Primorye Territory. Besides the studied area, we have seen it many times in the secondary oak forests of Lazovsky Nature Reserve (Primorye Territory, Russia) and Russky Island (Vladivostok, Primorye Territory, Russia).

*Amphinema byssoides (Pers.) J. Erikss. - angiosperm wood, gymnosperm wood (KUN ZMMU 2195, 2199, 2201, 2274); 2, 7.

*Amylocorticium Cebennense (Bourdot) Pouzar - angiosperm wood (KUN ZMMU 2010); 9.

*Amylocorticium subincarnatum (Peck) Pouzar - angiosperm wood (KUN ZMMU 2248); 9.

*ANTRodia Piceata K. Runnel, V. Spirin \& J. Vlasak - gymnosperm wood (KUN ZMMU 1984, 1985, 2085); 7, 9.

*AurantiPORUS FISSILIS (Berk. \& M.A. Curtis) H. Jahn ex Ryvarden - Quercus mongolica; 5.

*BASIDIODENDRON EYREI (Wakef.) Luck-Allen - angiosperm wood (KUN ZMMU 2325); 1.

*Botryobasidium Botryoideum (Overh.) Parmasto - angiosperm wood, gymnosperm wood (KUN ZMMU 2123, 2189, 2198, 2297); 2, $5,7,8$.

Note. According to our observations, B. botryoideum seems to be less rare than previously thought. In Russia, B. botryoideum occurs from the Far East (Langer, 1994; Spirin, unpublished) and Siberia (Shiryaev \& Kotiranta, 2015 (2016)) to the Komi Republic in Europe (Viner, 2015). Several collections were also made by I.V. in the secondary oak forests of Lazovsky Nature Reserve (Primorye Territory, Russia), which suggests that $B$. botryoideum can inhabit old-growth forests as well as disturbed forests with a limited amount of dead wood.

*BotryobasidIUM CONSPERSUM J. Erikss. - angiosperm wood (KUN ZMMU 2025, 2191, 2217); 1, 3, 7.

*Botryobasidium isabellinum (Fr.) D.P. Rogers - angiosperm wood (KUN ZMMU 2269); 8.

*Botryobasidium MEDIUM J. Erikss. - angiosperm wood (KUN ZMMU 2420); 5.

*BotRYOBASIDIUM OBTUSISPORUM J. Erikss. - angiosperm wood (KUN ZMMU 2096); 2.

*Botryobasidium SUBCORONATUM (Hohn. \& Litsch.) Donk - angiosperm wood, gymnosperm wood (KUN ZMMU 2240, 2244, 2264, 2394); $5,7,9$. 
**Cerinomyces aff. aculeatus N. Maek. - angiosperm wood (KUN ZMMU 2396, 2417; H7008652); 5, 8.

Note. Our material was in a good accordance with the original description of Cerinomyces aculeatus (Maekawa, 1987), although species delimitation is problematic before the sequencing of the type material (A. Savchenko pers. comm.) we prefer to denote it as $C$. aff. aculeatus. C. aculeatus was reported previously only from Japan (Shirouzu et al., 2009), so our findings represent the first records for Russia and Continental Eurasia. One collection was also made by I.V. in the secondary oak forests of Lazovsky Nature Reserve (Primorye Territory, Russia).

${ }^{*}$ CERIPORIA EXCELSA S. Lundell ex Parmasto - angiosperm wood (KUN ZMMU 2108); 2.

${ }^{*}$ Ceriporia purpurea (Fr.) Donk - angiosperm wood (KUN ZMMU 2333); 1.

${ }^{*}$ CERIPORIA VIRIDANS (Berk. \& Broome) Donk - angiosperm wood (KUN ZMMU 2324, 2327); 1.

CRYPTOPORUS VOLVATUS (Peck) Shear - gymnosperm wood (KUN ZMMU 2295); 8. Reported earlier in Korkishko (2002).

Note. According to our observations, C. volvatus inhabits only old-growth forests with a large amount of gymnosperm dead wood, which makes it vulnerable to forest loss in Primorye Territory.

*Dacryobolus Karstenil (Bres.) Oberw. ex Parmasto - angiosperm wood (KUN ZMMU 2272, 2551, 2552, 2553, 2556); 2, 5, 6, 7. Note. Our material was in good accordance with the original description, except having a bit thicker fruit body (1-2.5 vs $0.5-1$ $\mathrm{mm}$ ) and angiosperm wood as a substrate, which is unusual for $D$. karstenii (Eriksson \& Ryvarden, 1975).

*Dacryobolus sudans (Alb. \& Schwein.) Fr. - angiosperm wood (KUN ZMMU 2328); 1.

Note. Our specimen was collected on an angiosperm log which is an unusual substrate for D. sudans (Eriksson \& Ryvarden, 1975).

*Fomitiporia hartigiI (Allesch. \& Schnabl) Fiasson $\&$ Niemelä - Abies holophylla; 2.

*Galzinia incrustans (Hohn. \& Litsch.) Parmasto - angiosperm wood (KUN ZMMU 1997, 2003, 2086, 2088, 2100, 2121, 2122, 2125, 2126, 2184, 2216, 2252, 2254, 2265, 2304, 2306, 2397); 1, 2, 5, 6, 7.

*Gloiothele citrina (Pers.) Ginns \& G.W. Freeman - angiosperm wood (KUN ZMMU 2418); 9.
Hericium erinaceus (Bull.: Fr.) Pers. - Quercus robur. Reported earlier by Korkishko (2002) and Kovalenko et al. (2012).

Note. Besides the studied area, we have seen $H$. erinaceus many times growing on oaks in the secondary oak forests of Lazovsky Nature Reserve (Primorye Territory, Russia).

*Hymenochaete tenuis Peck - angiosperm wood (KUN ZMMU 2182); 6.

*Hyphoderma ARgillaceum (Bres.) Donk - angiosperm wood (KUN ZMMU 2170, 2324); 1, 2.

*HyphOdERMA INCRUSTATUM K.H. Larss. - angiosperm wood (KUN ZMMU 2101, 2188); 2, 7.

*HyPHODERMA obTUSUM J. Erikss. - angiosperm wood (KUN ZMMU 2270); 8.

*Hyphoderma Setigerum (Fr.) Donk - angiosperm wood (KUN ZMMU 2000, 2006, 2009, 2102, 2124, 2167, 2173, 2175, 2176, 2183, 2185, 2187, 2205, 2214, 2249, 2250, 2251, 2255, 2267, 2298, 2300, 2303); 1, 2, 5, 6, 7, 8.

*Hyphoderma sibiricum (Parmasto) J. Erikss. \& A. Strid - angiosperm wood (KUN ZMMU 2405); 7.

*Hyphodontia Alutaria (Burt) J. Erikss. - angiosperm wood (KUN ZMMU 2022, 2242); 3, 9.

*Hyphodontia pallidula (Bres.) J. Erikss. - angiosperm wood (KUN ZMMU 2245, 2246); 9.

*Hypochnicium albostramineum (Bres.) Hallenb. - angiosperm wood (KUN ZMMU 2189, 2257); $2,7$.

*Hypochnicium POLONEnse (Bres.) A. Strid - angiosperm wood (KUN ZMMU 1987); 9.

*InTEXTomyces contiguUs (P. Karst.) J. Erikss. \& Ryvarden - angiosperm wood (KUN ZMMU 2243); 9.

JUnGHUHNiA AURANTILAETA (Corner) Spirin - angiosperm wood (KUN ZMMU 2370, 2529, 2530); 6, 7, 8. GenBank Accession Number KY769581.

Note. J. aurantilaeta is known from Indonesia (Corner, 1989), Taiwan, Japan (Hattori \& Ryvarden, 1993) and China (Núñez \& Ryvarden, 1999). In Russia, it was also collected in the Bastak Nature Reserve, Jewish Autonomous Region, Russian Far East (Bukharova \& Zmitrovich, 2014).

*JunghuHnia Nitida (Pers.) Ryvarden - angiosperm wood (KUN ZMMU 2334, 2358, 2366); $1,2,8$.

*Membranomyces spurius (Bourd.) Jülich - angiosperm wood (KUN ZMMU 2313); 2.

*Odonticium flabelliRadiatum (J. Erikss. \& Hjortstam) Zmitr. - angiosperm wood (KUN ZMMU 2299, 2308); 6. 
*Oxyporus corticola (Fr.) Ryvarden - angiosperm wood (KUN ZMMU 2369); 8.

*Peniophorella praetermissa (P. Karst.) K.H. Larss. - angiosperm wood (KUN ZMMU 1991, 1999, 2001, 2016, 2024, 2070, 2097, 2098, 2099, 2110, 2127, 2206, 2256, 2416); $1,2,3,5,6,7,8$.

*Peniophorella pubera (Fr.) P. Karst. - angiosperm wood, gymnosperm wood (KUN ZMMU 2004, 2005, 2008, 2012, 2113, 2172, 2180, 2181, 2197, 2209, 2215, 2273, 2276, 2302); 1, 2, 6, 7, 8, 9.

Phanerochaete Robusta Parmasto - angiosperm wood (KUN ZMMU 2115, 2116); 2. Reported earlier by Korkishko (2002). GenBank Accession Number KY769582.

Note. In Russia, this species is known only from the Kedrovaya Pad Nature Reserve, but it also occurs in the adjacent part of China (Spirin et al., 2017).

*Phanerochaete sanguinea (Fr.) Pouzar - angiosperm wood (KUN ZMMU 2075); 7.

*Phanerochaete sordida (P. Karst.) J. Erikss. \& Ryvarden - angiosperm wood (KUN ZMMU 2076); 7.

*Phellinus contiguus (Pers.) Pat. - angiosperm wood (KUN ZMMU 2271, 2322); 1, 8.

*Phlebia lilascens (Bourdot) J. Erikss. \& Hjortstam - angiosperm wood (KUN ZMMU 2395); 5.

*Phlebia livida (Pers.: Fr.) Bres. - angiosperm wood (KUN ZMMU 2329, 2330, 2335, 2359, 2365, 2368); 1, 2, 8.

*Phlebia RADIATA Fr. - angiosperm wood (KUN ZMMU 2514); 6.

*Phlebia RUfa (Pers.) M.P. Christ. - angiosperm wood (KUN ZMMU 2402); 6.

*PoROtheleum FIMBRiatum (Pers.) Fr. - angiosperm wood, Pinus koraiensis (KUN ZMMU 2545, 2548); 2, 6.

*Postia lateritia Renvall - Pinus koraiensis (KUN ZMMU 2546); 2.

*Postia tephroleuca (Fr.) Jülich - angiosperm wood (KUN ZMMU 2337); 1.

**Pyrrhoderma cf. Sendaiense (Yasuda) Imazeki - angiosperm wood, gymnosperm wood (KUN ZMMU 2177, 2196, 2210, 2296; H7008653); 2, 8. GenBank Accession Number KY769583.

Note. Basidiocarps annual, but hard and corky, centrally stipitate to substipitate. Stipe 3-4 cm long and $1.5 \mathrm{~cm}$ thick; pileus with obtuse margin applanate, circular, sometimes lobed, solitary or branching from a common base, projecting up to $6 \mathrm{~cm}$. Pileal surface yellowish-brown to reddish-brown, glabrous, faintly concentrically zonate. Pore surface yellowish-brown to dull-brown, the pores circular, 5-6 per $\mathrm{mm}$, with thick, entire dissepiments. Context yellowish-brown to brown, hard-fibrous with distinct brown layer in the upper part delimiting a cuticle. Tubes slightly paler than context, up to 3 mm long (Fig. 3).

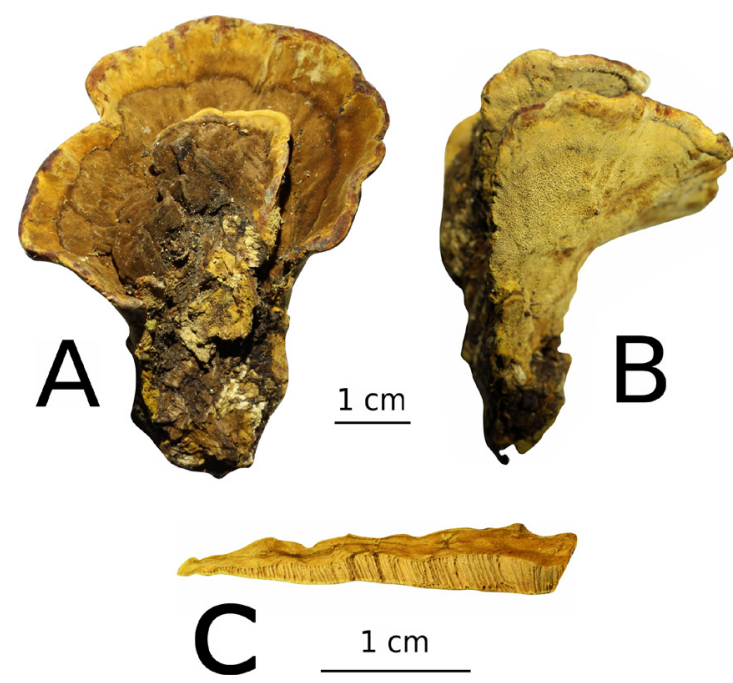

Fig. 3. Pyrrhoderma cf. sendaiense (Yasuda) Imazeki (KUN ZMMU 2177): A - pileal surface, B stipe and pore surface, $\mathrm{C}$ - context and tubes.

Hyphal system monomitic, simple-septate and with fairly frequent septa, faintly positive in CB. Hyphae of context pale yellowish in $\mathrm{CB}$, thick-walled, straight, rarely branched, 6-11 $\mu \mathrm{m}$ in diam. Hyphae in the cuticle hyaline and thick-walled, arranged into a palisade, 5.5-9 $\mu \mathrm{m}$ in diam, sometimes encrusted. A layer of dark-brown hyphae underlying the cuticle, these hyphae distinctly thick-walled, 5-7 $\mu \mathrm{m}$ in diam. Tramal hyphae yellowish-brown to pale yellowish, arranged parallel along the tubes. 2.5-5 $\mu \mathrm{m}$ in diam. Setae abcent. Basidia 13-16 $\times 6.8-9 \mu \mathrm{m}$, clavate, tetrasterigmatic, simple septate at the base. Basidiospores subglobose, hyaline, thin-walled, smooth, negative in IKI, faintly positive in CB, 5.6-7.3 $\times 4.5-5.6 \mu \mathrm{m}$, with distinct oily droplet (Fig. $4)$. 


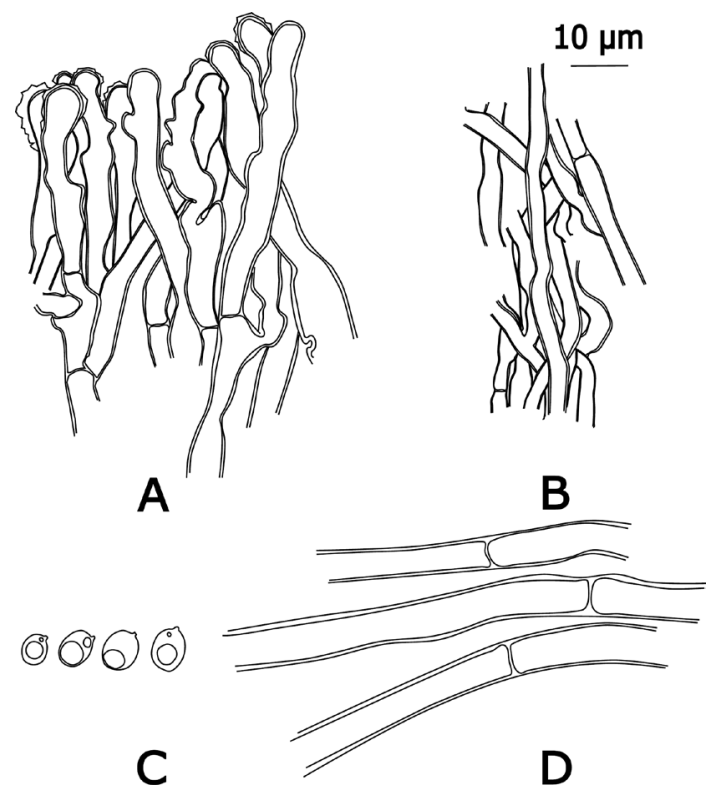

Fig. 4. Pyrrhoderma cf. sendaiense (Yasuda) Imazeki (KUN ZMMU 2296): A - palisade cells from cuticle, B - hyphae from trama, C - spores, D - hyphae from context.

Our specimens seem to be close to Pyrrhoderma sendaiense. Nevertheless, we prefer to denote them as Pyrrhoderma cf. sendaiense, since the genus Pyrrhoderma is polyphyletic and has poor morphological species delimitation (Spirin, unpublished), so for proper species delimitation further studies of type specimens with sequencing are needed. Our material was compared with specimens from Khabarovsk Territory, Russian Far East (Spirin, unpublished) and they seem to be the same.

*REPETOBASIDIUM MIRIFICUM J. Erikss. - angiosperm wood (KUN ZMMU 2321, 2525); 1, 5.

*Rhizochaete filamentosa (Berk. \& M.A. Curtis) Gresl., Nakasone \& Rajchenb. - angiosperm wood (KUN ZMMU 2512, 2513); 2.

*SCOPUlOIDES RIMOSA (W.B. Cooke) Jülich - angiosperm wood (KUN ZMMU 2002, 2011); 9.

*Sidera VUlgaris (Fr.) Miettinen - angiosperm wood (KUN ZMMU 2084); 5.

*Sistotrema BRinKMANNII (Bres.) J. Erikss. - angiosperm wood (KUN ZMMU 2315); 2.

*Sistotrema octosporum (J. Schrot. ex Hohn. \& Litsch.) Hallenb. - angiosperm wood (KUN ZMMU 2111); 2.
*Sistotrema porulosum Hallenb. - angiosperm wood (KUN ZMMU 2077, 2207); 7, 8.

*Sistotremastrum niveocremeum (Hohn. \& Litsch.) J. Erikss. - angiosperm wood (KUN ZMMU 2112, 2406); 2.

*Sistotremastrum SUECicum Litsch. ex J. Erikss. - angiosperm wood (KUN ZMMU 2531); 4.

*Skeletocutis NIVEA (Jungh.) Jean Keller - angiosperm wood (KUN ZMMU 2027, 2078, 2128, 2129, 2239, 2332, 2360, 2364); 1, 2, 3, 5, 6.

*Sphaerobasidium minutum (J. Erikss.) Oberw. ex Jülich - angiosperm wood (KUN ZMMU 2266); 5.

*STECCHERINUM MURASHKINSKYI (Burt) Maas Geest. - angiosperm wood (KUN ZMMU 2106); 2.

*Steccherinum tenuispinum Spirin, Zmitr. \& Malysheva - angiosperm wood (KUN ZMMU 2363); 2.

*Subulicystidium Longisporum (Pat.) Parmasto angiosperm wood (KUN ZMMU 2171, 2307); 2,6 .

*Trechispora stellulata (Bourdot \& Galzin) Liberta - angiosperm wood (KUN ZMMU 2213); 1.

*TUBULICRINIS CALOTHRIX (Pat.) Donk - angiosperm wood (KUN ZMMU 2178, 2258); 2, 7.

*TyROMYCES Chioneus (Fr.) P. Karst. - angiosperm wood (KUN ZMMU 2532, 2533, 2534); 2, $6,7$.

*Tyromyces wynneae (Berk. \& Broome) Donk angiosperm wood (KUN ZMMU 2547); 9. GenBank Accession Number KY795989.

Note. This species has a sporadic distribution all over the Europe (Ryvarden \& Melo, 2014), Caucasus (Khacheva, 2016) and Siberia (Vlasenko, 2013). Thus, our finding is the most easternmost in Eurasia at present.

*Xenasma PRAeteritum (H.S. Jacks.) Donk - angiosperm wood (KUN ZMMU 1995, 1996, 2072, 2179, 2247); 6, 7, 9.

Note. X. praeteritium is rarely collected in Russia and we failed to find any published record of this species in Russia except Russian Caucasus (Ghobad-Nejhad et al., 2009). Nevertheless, it seems to be common species in the studied area, which can growth on large-sized angiosperm logs as well as small twigs.

*Xenasmatella BoRealis (K.H. Larss. \& Hjortstam) Duhem - angiosperm wood (KUN ZMMU 1995); 6.

*Xenasmatella christiansenil (Parmasto) Stalpers - angiosperm wood (KUN ZMMU 2398, 2399); 5. 
*Xenasmatella fibrillosa (Hallenb.) Stalpers angiosperm wood (KUN ZMMU 2119, 2208, 2528); 2, 5, 8.

*Xylobolus frustulatus (Pers.) P. Karst. - Quercus mongolica (KUN ZMMU 2026); 3.

*Xylodon asperus (Fr.) Hjortstam \& Ryvarden angiosperm wood, gymnosperm wood (KUN ZMMU 1992, 2241); 9.

*Xylodon bugellensis (Ces.) Hjortstam \& Ryvarden sensu Bernicchia and Gorjón (2010) - gymnosperm wood (KUN ZMMU 2727); 2.

*XYlODON NESPORI (Bres.) Hjortstam \& Ryvarden - angiosperm wood (KUN ZMMU 2007); 6.

\section{ACKNOWLEDGEMENTS}

We would like to thank Viacheslav A. Spirin and Anton A. Savchenko for consultation in identification of some species and the anonymous reviewers for valuable comments on the manuscript. We are grateful for the support from the Kedrovaya Pad Nature Reserve. Our special thanks are also due to Gleb A. Sedash and Dina S. Matiukhina for the warm hospitality and support during our visit. I.V. was supported by the Russian Foundation for Basic Research, project 14-04-01423a and L.K. by the Russian Science Foundation (project N 14-50-00029).

\section{REFERENCES}

Abarenkov, K., Tedersoo, L., Nilsson, R., H., Vellak, K., Saar, I., Veldre, V., Parmasto, E., Prous, M., Aan, A., Ots, M., Kurina, O., Ostonen, I., Jõgeva, J., Halapuu, S., Põldmaa, K., Toots, M., Truu J., Larsson K-H. \& Kõljalg U. 2010. PlutoF - a Web Based Workbench for Ecological and Taxonomic Research, with an Online Implementation for Fungal ITS Sequences. Evolutionary Bioinformatics Online 6: 189-196. https://doi.org/10.4137/ EBO.S6271

Baryshenko, A. P. 2008. The Red Book of the Primorye Territory: Plants. Rare and Endangered Species of Plants and Fungi (in Russian). Vladivostok. $688 \mathrm{pp}$.

Bukharova, N. V. \& Zmitrovich, I. V. 2014. Aphyllophoroid fungi of the "Bastak" reserve (in Russian, English summary). Mikologiya $i$ Fitopatologiya 48(6): 343-354.

Corner, E. J. H. 1989: Ad Polyporaceas 5. Beih. Nova Hedwigia 96: 1-218.

Dai, Y.-C., Niemelä, T. \& Kinnunen, J. 2002. The polypore genera Abundisporus and Perenniporia (Basidiomycota) in China, with notes on Haploporus. Annales Botanici Fennici 39(3): 169-182.
Eriksson, J. \& Ryvarden, L. 1975. The Corticiaceae of North Europe 3. Coronicium to Hyphoderma, pp. 287-546. Fungiflora, Oslo.

Ghobad-Nejhad, M., Hallenberg, N., Parmasto, E. \& Kotiranta, H. 2009. A first annotated checklist of corticioid and polypore basidiomycetes of the Caucasus region. Mycologia Balcanica 6: 123-168.

Griffith, G. W. \& Shaw, D. S. 1998. Polymorphisms in Phytophthora infestans: four mitochondrial haplotypes are detected after PCR amplification of DNA from pure cultures or from host lesions. Applied and environmental microbiology 64(10): 4007-4014.

Hattori, T. \& Ryvarden, L. 1993. Antrodiella aurantilaeta, a new polypore to Japan. Transactions of the Mycological Society of Japan 34: 363-368.

Index Fungorum (http:/ /www.indexfungorum.org/), 30.03.2017.

Khacheva, S. I. 2016 Altitude Features of aphyllophoroid fungi biota in the Republic of Abkhazia. Sustainable development of mountain territories 8(4): 368-377.

Korkishko, R. I. 2002. The list of plants and fungi of the reserve "Kedrovaya Pad", check-list of species (in Russian). Vladivostok. 157 pp.

Kovalenko, A. E., Psurtseva, N. V., Malysheva, V. F., Malysheva, E. F., Svetasheva, T. Yu., Kiyashko, A. A. \& Andreeva, A. N. 2012. Studiyng basidiomycetes of the "Kedrovaya Pad" reserve and the "Leopardovy" sanctuary. Scientific report on the results of the mycological expedition in 2011. (in Russian). Botanical Institute VL Komarova of the Russian Academy of Sciences, St. Petersburg.

Langer, G. 1994. Die Gattung Botryobasidium Donk (Corticiaceae, Basidiomycetes). Bibliotheca Mycologica 158: 1-459.

Maekawa, N. 1987. A new species of the genus Cerinomyces. Canadian Journal of Botany 65(3): 583-588. https://doi.org/10.1139/b87-074

MycoBank (http:/ / www.mycobank.org/), 29.02.2016.

Nikolayeva, T. L. 1967. Hydnaceous fungi fungi of the Amur region, Khabarovsk and Primorye Territory (in Russian). Novosti sistematiki nizshikh rasteniy 4: 237-243.

Núñez, M. \& Ryvarden, L. 1999. New and interesting polypores from Japan. Fungal Diversity 3: 107-121.

Parmasto, E. 1968. Conspectus systematis Corticiacearum (in Russian). Tartu. $261 \mathrm{pp}$.

Parmasto, E. 1970. The Lachnocladiaceae of the Soviet Union (in Russian). Tartu. 204 pp.

Ryvarden, L. \& Melo, I. 2014. Poroid fungi of Europe. Synopsis Fungorum 31: 1-455.

Shirouzu, T., Hirose, D. \& Tokumasu, S. 2009. Taxonomic study of the Japanese Dacrymycetes. Persoonia 23: 16. https://doi. org/ 10.3767/003158509X468443

Shiryaev, A. G. \& Kotiranta, H. 2015 (2016): Aphyllophoroid fungi (Basidiomycota) of the middle 
part of Yenisei River basin, East Siberia, Russia. Karstenia 55: 43-60.

Spirin, V., Volobuev, S., Okun, M., Miettinen, O. \& Larsson, K-H. 2017. What is the type species of Phanerochaete (Polyporales, Basidiomycota)? Mycological Progress 1-13. https:/ / doi.org/10.1007/ s11557-016-1267-8

Spirin, W, Zmitrovitch, I. \& Malysheva, V. 2007. New species in Junghuhnia (Polyporales, Basidiomycota). Annales Botanici Fennici 44: 303-308.

Vassiljeva, L. N. 1972. Basidiomycetes of the reserve "Kedrovaya Pad". In: Oraeva, A. (ed.). Flora and vegetation of the reserve "Kedrovaya Pad" (in Russian). Vladivostok. 145-168.

Viner, I. A. 2015. Polyporoid and corticioid Basidiomycetes in pristine forests of the Pechora-Ilych
Nature Reserve, Komi Republic, Russia. Folia Cryptogamica Estonica 52: 81-88. https://doi. org/ $10.12697 /$ fce.2015.52.10

Vlasenko, V.A. 2013. Ecological characteristics of bracket fungi in the forest steppe of Western Siberia. Contemporary Problems of Ecology 6(4): 390-395. https://doi.org/10.1134/ S1995425513040136

White, T. J., Bruns, T., Lee, S. J. W. T. \& Taylor, J. W. 1990. Amplification and direct sequencing of fungal ribosomal RNA genes for phylogenetics. PCR protocols: a guide to methods and applications 18(1): 315-322. https://doi.org/10.1016/ b978-0-12-372180-8.50042-1 